\title{
EDUCATION IN CONTEMPORARY NIGERIA: TRENDS, CHALLENGES AND THE WAY FORWARD
}

\author{
Dr.OMORAKA, VICTOR; Dr.BELLO MUHAMMED SHALLAH AND \\ Dr. MOHAMMED IBRAHIM
}

\begin{abstract}
There are diverse challenges confronting humanity inthe $21^{\text {st }}$ century. Education in contemporary Nigeria is confronted with several of such challenges. This paper $x$-rays the challenges confronting the Nigerian Education system at all levels, especially in the last decade and offers suggestions on the way forward for the attainment of improved, qualitative education delivery in Nigeria. The paper concludes that if the suggested solutions to the diagnosed ailments to the education system are implemented, the present influx of Nigerian students to other countries will be checked and the pathway towards greatness will be realistically open.
\end{abstract}

\section{Introduction}

Education is the process by which a society prepares its members, particularly the children, teenagers and young adults, for good orcomplete living in adult life.It is an organised set of articulated procedures or ways of equipping people with the right skills, attitude and value orientation as a basis for appreciating and enjoying what they met in place and being able to make positive contributions towards improving theindividual self, others and the larger society. In a formal sense, the educational processes are carried outthrough schools, colleges or universities.Usually, it is an endeavour for which government, in modern societies, take responsibility for policy formulations, implementation and regulation. The above view is incumbent on the elucidations proffered by other writers who see the planned educative process as a means by which society captures, preserves, constructs, andorganizes its cultural heritage and transmit same to successive generations in pursuance of the overall goal of positive social change, economic productivity and national development (Dewey,2007; Ebuta,2012; Akinkpelu,2005).

In a modern world, the education system is the spearhead that launches nations into global limelight.It is the dependable means of improving knowledge and developing skills capable of systematically transforming a nation's population endowment into a productively capable, comprehensivelysociable, morally disposed, united and purposeful workforce that engages both natural and acquired resources for the production of economic goods and services upon which individual and societal existence depends (Omoraka,2009). Well-Strand (2000) also asserts that for a country to remain relevant in today's competitive knowledge economy, quality and reputation of it's education institutions and programmes must be visibly eminent and prioritized. Education, to this extent, is what determines the level of wealth or economic advancement attainable by a nation. This is so because, in the opinion of Okandeji, (2007), if a nation is blessed with huge natural resources and a human population of considerable size without a relevant functional education system, such a nation will continue to wallow in poverty and underdevelopment. The developed nations of the world including theUnited States of America, GreatBritain, China, Japan, Germany etc, acted promptly on the realization of the value and power of education to take them to the great height of privileged economic strength and prosperity, the prestige of which they now enjoy. 
My dear country, Nigeria, is yet to wake-up from the slumber of educational mediocrity. The huge national resources bequeathed to our country by nature are still largely untapped. Where any amount of exploration or exploitation has been done, expatriates who own multinational companies with the righttechnological skills and knowledge have remained the key players. This is the inherently tenable situation in our oil and gas, steel,railway and construction sectors, and increasingly the power sector also. This nation has continued to wobble along like an incapacitated giant for one hundred years. No doubt, our natural resources are immense indeed. We have over 37.2 billion barrels of crude oil reserves in Nigeria, placing the country as the largest oil producer in Africa and the $11^{\text {th }}$ largest custodian of oil reserves in the world, averaging 2.28 million barrels per day (ASB-NNPC, 2004). With this position we have only one reason to remaining congruently underdeveloped which is the poor conduct of the country's educational affairs. It is also note worthy that different commercial quantities of a variety of solid minerals have since remained unattended to for conversion into the needed products for home use and gainful exportation. These include barites, gypsum diatomite, clay dolomite, kaolin talc, lime stone, talc, bismuth, granite, magnetite, marble, phosphate, quartzite, silica, gold, coal, bitumen, iron ore, lead, zinc, manganese, lithium, tantalite and silver.These can be found in different parts of the Nigeria. What about the available amount of potential sources of energy in Nigeria that are yet largely unutilized: renewable energy from solar, wind, water/hydrogen,Sea, biomass, geothermal energy, etc. These priceless natural endowments have in many cases been left unappreciated, unexplored and most painfully wasted.

Beyond all these aforementioned, Nigeria is favourably endowed with a large human population. This asset is naturally a required factor to realize the social-economic value of the material resources identifiable in a Nation. Unfortunately, this large population is being viewed as a colossal hindrance to the development of Nigeria. The questions that critically arise now are: What have been the structures and processes of the Nigerian system of education?Where can the missing link be located? What are the consequences of the present educational foot dragging?Is our present developmental position not an irony? A historical view of trends in the sector might be enlightening in this respect.

Educational Trends in NigeriaAs mentioned earlier, a developed education system, no matter the form it takes, is a pre-condition for the developmental uplifting of a nation. The Nigerian education system has developed too slowly over the years. The outcomes of various evaluationprogrammes at different periods of our national history have, in accordance, led to appropriate, periodic policy reforms far back in Nigeria's educational history. The main challenge has been the lack of political will tofund and implement reforms for realistic and practical transformation value.

Beginning with the Christian missionary effort to educate the natives, particularly in southern Nigeria, with the goal of converting them to the Christian religion and making them receptive to the British culture, the education system, before long, came under the influence and control of Colonial Masters who were prepared to give only a straight education that enabled the learners to relate effectively with the British Administrators, expecting school leavers to work as messengers, clerks etc in the day-to-day administration of the colony.For decades, critical thinking, scientific and technological skills were deliberately uninvolved (Fafunwa,1972). Was there any remarkable restructuring and organization of the sector for greater viability after the attainment of political independence? 


\section{Post independence/Modern Education in Nigeria}

Widespread dissatisfaction with the inherited colonial education system years after independence led to major policy reforms on the system in the late 70's giving rise to the implementation of a new model of education known as the 6-3-3-4 system. It was structured with the needs of the Nigerian society in focus. In it, the school curriculum was made more inclusive and broad-based. This became what is known as modern education in Nigerian historical notations.

Consequently, the Nigerian education system, in its modern form and dispensation, has attracted more effort towards making it less intellectual and more functional and utilitarian in design. Recently in 2004, the lower levels have been restructured by the federal government to come up with the Universal Basic Education (UBE) System. This was a visionary programme introduced by the Government of Nigeria to remove distortions and inconsistencies in basic education delivery. The motive was also to reinforce the implementation of the existing National Policy on Education as well as provide greater access to and ensuring quality of basic education throughout Nigeria (Bukar, Mwajim,\&Kadiri,2012). This is where we now stand regarding secondary education as a feeder level to the tertiary education level both of which are critical for advancement and achievement of the articulated national goals. On this bases, how can Nigeria, in the global sense, attainher national goals and realize her vision?

\section{National Goals of Nigeria and Vision 20:2020}

It is worth mentioning that Nigeria has always proclaimed a good number of laudable national objectives, some of which we can mention here. Nigeria desires to be truly a free, just and democratic society; a land of full and bright opportunities for all its citizens; able to generate a great and dynamic economy and grow into a united, strong and self-reliant nation (FGN,2004). It needs be restated here that it is only through the instrument of education that these national desires can be realized and sustained. The goal of vision 20:2020 of Nigeria becoming one of the twenty most advanced nations of the world by the year 2020 is thus in consonance with the declared national objectives of Nigeria. Consequently, modern education in Nigeria is expected to produce men and women fully prepared, brave, confident and nationally conscious in character and learning. In this way Nigerians can be made happier, free from hunger, pains and poverty and the country can become a better and secure place for living. This is what development is all about. It is sad to note that inspite of the well formulated education policies, a large and vibrant human population and huge endowment with abundant natural resources, the Nigerian nation is still far from reachingthe expected development level. The challenge now is in the way and manner our instrument of advancement which is education is being conducted. This is why we need to rescan our educational policy implementation strategies to highlight major challenges and work towards creating possibilities for a brighter prospect.

\section{Major challenges of education in Nigeria}

The Nigerian education system has been in a critical condition for over a decade now. Among the issues bedeviling the system is the underfunding of educationat both the Federal, State and local governmentlevels. We have heard of the increasing number of educational institutions across the country. But beyond their establishment, lip service is 
paid to their maintenance for quality and sustained viability (Iyamah, 2009). The Federal government is still spending below $10 \%$ of its annual expenditure on educational system development and implementation (Mahmoud, \&Madori, 2013). This is a far cry from the UNESCO recommendation of $26 \%$ of the national budget of member countries on education and the human capital developmentprogrammes generally. This is made worse by low counterpart funding by the private sector and communities. The loud and repeated message that government alone cannot fund education is yet to be imbibed. Consequently, in many of the schools, classrooms, libraries and laboratories are nothing to write home about, adecriable fact which educational unions and public education practitioners have insistently declared unacceptable. This has invariably led to a decline in the standard of education to the extent that certificates from Nigerian secondary and higher institutions are accepted with doubts by employers of educated, skilled labour. Therefore, attempts to revitalize educational institutions must begin with the issue of adequate funding. Funding is key to reversing the downward trend in our educational fortunes. Appreciably, the Nigerian federal government has recently released two hundred billion naira towards higher education funding in the country. This was not achieved without a prolonged strike of about six months by university lecturers throughout the country. How far this will genuinely go in the improvement of this critical sector is yet to be determined

A consistent manifestationfrom the above development is the observed dwindling level of procurement of technical and scientific equipment, books, journals, furniture and other instructional materials needed in the educational system. Undeniably, these are critical necessities for qualitative education delivery. Even the teachers, particularly at the foundational primary and secondary school levels, do their job without motivation because teachers' welfare matters are treated with levity by both the government and private school proprietors. Invariably therefore, teachers do not exhibit total commitment to their strategic role in the system (Asabor, 2009).

The issue of examination malpractice is also a down-tracker of the system. This monster has remained untamed due to obnoxious parental support for their lazy children and corrupt examination officials and school teachers who master-mind the evil practice.

Another malaise besetting the education system of Nigeria has been the senseless conflict between the Federal, State, and Local Governments in the management of education at various level. This is the reason for the ambivalent position of primary schools in terms of responsibilities and control functions. At the basic education level, this has been a great barrier leading to systemic crises and imminent drastic failures.

On the part of students, there has been a decline in general interest to pursue academic excellence in schools. Increasingly, students are more anxious about when they will leave school and be free from studies rather than think of how to actually acquire knowledge and skills which they can apply in contributing to the betterment of society. This attitude is precipitated on the bad teaching methods adopted by a good number of unqualified teaching staff engaged in many of our schools. This, of course, is an offshoot from the problem of how politicians influence teachers recruitment exercises organized by school boards and officials of the education ministries.

In many cases, prospective teachers are not recruited on the basis of performance in well supervised selection examinations such as aptitude tests and stringent oral interview formalities. Consequently, qualified persons without political god fathers are regrettably 
dropped to create positions for favorites of politicians, believing wrongly that anyone can teach in a school .Such incompetent teachers end up killing students interest in learning and leading to mass failure in public examinations. The uproar about poor performance in the Senior School Certificate Examination in the country attests to this regrettable fact about the Nigerian Secondary School System.

Bureaucratic corruption identified by Jain (2001) as theillegal practices often perpetrated by appointed bureaucrats or the civil and public servants, is exerting its monstrous effect on the education sector.Embezzlement of funds meant for the development of education by corrupt school heads and education managers remains a cankerworm that is destructively eating deep into the system of Nigerian education. This directly accounts for lack of facilities such as computers, laboratories and workshops for practical activities in the learning of school subjects. Efforts must be made to demand accountability for financial resources which institutions receivein the form of subventions to the schools by government and donations from good-spirited concerned individuals.

Worthy of mention also is the intractable proliferation of sub-standard private schools across the Nigeria in recent years. They often show-up as institutions established to fill the gap created by failures on the part of government in the provision of adequate access to education for the teaming youth and young children. In the true sense however, they are run, in many cases, as money-making outfits. Some of the owners have no relevant professional training on educational affairs. They therefore lack overall passion to ensure effective education of their student clients. It is commendable that some state governments in Nigeria have, in recent times, closed down a number of such mushroom and illegal schools. This is a drastic step that will go a long way in reducing the production of half-baked school leavers who might later constitute a threat to national security. Only standard schools should rightly be registered to operate under periodic inspection by appropriate government educational agencies.

Closely related to the above is the unwholesome practice of rendering false reports about school situations and conditions of learning. Commissioners and Ministers or even local government chairmen who depend on only second-hand information from official reports will continue to be misguided. Funny enough, most persons whose official assignments involve the management of the education system at different levels in Nigeriado not have their children or wards in the schools under their control and which they claim responsibility for. Their children, in most cases are indisputably either schooling in other countries and enjoying their education or learning in some prestigious private educational institutions outside their domains of supervisory jurisprudence. This is an anomaly because, being a non-stakeholder in the system, such an educational controller can hardly be truly committed to improving the situation. Regrettably, the teachers on the field are never consulted and heard. Their reports are never sort for even when it is clear that they know the real situation better and may possess superior and more feasible suggestions to offer. Leaders of the education sub-sector must solicit the views of the field workers, the teachers themselves, and be guided accordingly. Failure in this respect has protractedly hindered educational improvements in Nigeria because government is inadvertently misled into unnecessary confrontation with teachers.

The challenges of the Nigerian education system are not exclusively akin to the lower levels. At the tertiary echelon of the educational ladder, we also have a system fraught with peculiar ailments. Inspite of the massive collaboration to deal with indiscipline in 
Nigerian higher institutions, cultism and various forms of violence still strive in some institutions. By their heinous activities they have created mayhem of different sorts thereby disrupting academic activities which invariably affect institutional calendars of teaching, learning and research.

Nigerian universities are yet to embrace the concept of functional education, entrepreneurial and vocational adaptivness as a curriculum imperative for turning out employment creators. Annually thousands of employment seekers are being turned out because the system is still suffering from strategic utilitarian dysfunctionality. This trend must, of necessity, be reversed. Conscious effort is needed by all stakeholders in the University education sub-sector, including government at the Federal and state levels, private university owners, tertiary education managers, lecturers, instructors and even the students themselves in order to weave University education around productivity and equipment for contributing to nation building and development initiatives among graduates.

The University must not only incubate ideas but must, as a matter of policy, relate with industries or the private sector to translate ideas and research findings into products and services to boost developmental advancement.

Once this tactical relationship is firmly created between the three arms, then progress, achievement and national development will be accelerated.

Overcrowding of students in tertiary institutions in Nigeria is another perpetual phenomenon that tends to negatively tamper with teaching and learning quality. The enrolment capacity of Nigerian higher institutions put together is about five thousand $(500,000)$. But each year an average of 1.3 million candidates write the admissions and matriculation examination (JAMB), seeking entrance to higher institutions. In the year 2013, over 1.6 million candidates enrolled for the entrance examination (JAMB) to tertiary institutions in Nigeria (JAMB, 2013). This brings to focus the problem of access and potential pressure on institutions toadmit beyond their carriage capacity. The consequence is that undue pressure is put on facilities including environmental resource installations, lecture halls, workshops, laboratories, hostel facilities, library etc, all of which have led to a decline in the standard of education due to frustration and limitation on lecturers' instructional capabilities.

It is instructive to note that there is excessive demand for Higher Education in Nigeria. School leavers are no longer interested in learning any trade, thereby defeating the sector goal of the Universal Basic Education initiative.

The challenges of the education system at all levels in Nigeria have made it largely impossible to guarantee the production of the desired high quality workforce needed to drive the machinery to national development.

\section{The Way Forward}

We cannot continue to bemoan the obstacles on Nigeria's match towards techno logical advancement, national Security, social integration and global relevance. The following suggestions are hereby presented for implementation to bring about needed recovery and modernization of the system: 
1. Government should begin with a systematic diagnosis of the chronic ailment in the education system in order to effectively take proper steps towards recovery in the sector. Beginning with a national conference initiative where all stakeholders will contribute generously towards efforts to reforms the Nigerian Education System will be a strategic take-off option.

2. Appropriate budgetary provisions must be made towards funding education in Nigeria. In this way, the problem of inadequacies in facilities and resources will be effectively tackled. The needs assessment report on the Nigerian tertiary institutions should be considered seriously and appropriate short term and long term plans made to address them to avoid impending system collapse of the sector.

3. Indiscipline and all forms of corrupt practices by those involved in the management of education at all levels should be brought under check. Education funding cannot make sense if government budgetary allocations are diverted and misappropriated with impunity. The various anti-corruption agencies in the country should begin a closer watch on the sector. This should also be corroborated by auditoral monitoring committees to ensure greater probity in the higher education sub-sector.

4. Teachers' and Lecturers' welfare should be given more consideration as key contributors to national development. Teaching staff should be attended to in line with global trends. This will ultimately arrest the brain-drain syndrome and ensure teaching staff stability in the system. It is often said that no education system can rise above the quality and motivational disposition of the teachers it retains.

5. Moreover, strong political will is required on the part of government with regards to the administration of prescriptions to the identified system ailments. Over the years, conference and workshop outcomes where either discarded or haphazardly implemented. This attitude must be thoughtfully and radically reversed.

6. Government at all levels should have no option than to honour agreements reached with educational workers to avoid industrial crisis in the system. More often than not, the government is misled by overzealous politicians appointed into educational management committees, governing councils and Boards, thus causing government confrontation with teachers and lecturers. This baneful legacy should cease forthwith.

7. At the primary and secondary school levels, good school governance should receive renewed emphasis backed up by necessary regulatory laws. School management committees(SMC) should be implemented with representations from communities, government and the industrial sector.

8. Admission into schools, especially tertiary institutions, should be based only on merit. Students who justify their admission into such schools are less prone to anti-social behaviours in campuses.

9. Although the establishment of more Federal Universities is a justified decision, quality education should not be sacrificed on the alter of increased access to schooling opportunities. Effort must continue to be directed towards ensuring that there is a sensitive balance between access and quality in the dispensation of education in Nigeria.

10. Employment of only qualified professional teachers should be ensured in the system. The recruitment of teaching staff should be more stringent and thorough, involving the use of aptitude tests to determine intellectual competence. 
Transparency should be key to the recruitment and engagement process. Enough of professional mediocrity in the system.

11. Findings from research works should not just be left on the shelves of research institutions. Rather, privately sponsored agencies should collect them with a view to translating them into products and services for national development. To this end, relevant agencies of government should be involved in the collation of research sponsorship efforts and outcomes to minimize the existing gap between research outputs and industrial or corporate applications for economic productivity. This will be in furtherance of a cyclical relationship among the industry, government and academia which is an imperative for improving the functionality component in the education package.

12. Unqualified school owners and sub-standard schools should be tolerated no further. Such schools should be closed down after due confirmation of their illegalities.

13. Random, frequent introduction of educational reforms based, not on evaluation reports but on political whims, must be discouraged. This also, it must be pointed out, includes allocation of educational institutions to certain geographical areas on the basis of ethnicity, tribe or political affiliations instead of doing so on the basis of exigency and identified needs.

14. Because government alone cannot provide the needed solutions, individuals, religious organizations, corporate bodies and community development executives must be ready to partner with the government to realize the dividends of a workable and developmentally sensitized education system in Nigeria. This is an era of Public-Private-Partnership (PPP) and the education sub-sector cannot be left out. But this should not be done through the donations of some politicians who, because of approaching election campaign periods, rush to award contracts to build sub-standard classroom blocks in their community schools. In most cases, these contracts are awarded to incompetent contractors who use sub-standard materials and do poor finishing on the buildings and furnishing. To avoid this, school heads and managers should be carried along by getting them involved in the design and supervision of such projects right to the completion stage. Poor performance by contractors handling projects in the sector is even common in tertiary institutions.

15. Students should be involved in the decision making process to enable institutions have an opportunity of benefitting from students view point. In this regard therefore, it is suggested that instead of the usual "Parents/Teachers Association" we should be talking of "Parents-Teacher- Students Association(PTSA) in our Secondary Schools. At the Tertiary institutions level, more ways should also be devised to give more voice to mature representatives of the student bodies. This will go a long way to reduce student agitations that often lead to closure of schools and disruption of academic programmes and calendars.

16. More efforts should be made towards reviving vocational and technical training in Nigeria. Government should provide better enabling environment where companies receive school leavers for vocational skills development programmes. University graduates in the technical and engineering fields should also be given more of such creative opportunities and industrial exposure. Functional education can hardly be realized without these ancillary ingredients of technological skills enrichment. It is usually expensive to train people to acquire technical skills but they are in high demand for the development of a nation's economic base. The present situation whereby the nation's polytechnics are allowed to remain closed 
for several months is a baneful legacy which government must do all it can to curb. Accordingly, all stake holders in the matter should, in the interest of the nation, show adequate commitment to resolve all perceived and real crises affecting the system.

17. Furtherance to the above, standard roadside workshops can be integrated into participating in the provision of training for candidates who have completed the Junior Secondary education level but lack what it take to proceed further in academic pursuit. Japanese practice is an example of this approach. Such duly registered skill-training providers are to be given vocational training curricular packages which specify training duration, methods, sequence of coverage on the content outline, and evaluation modalities. Such a syllabus will be prepared by the workshop masters under the guidance of experts in the field of curriculum development and training technology.

18. Information and Communication Technology (ICT) has been globally acknowledged as the bed rock of scientific and technological development. Accordingly, Nigerian educational institutions should be made to showcase large pools of personal computer units operated in environments that are internet supported and operational. A situation where engineering and technical educators continue to adopt inefficient, slow and ineffective instructional materials can lead us nowhere. Whatever it takes, obsolete models and equipment should be discarded and replaced by state-of-the-art equipment, software and other information/ digital programmes.

19. Government should continue the vigorous pursuit of the transformation effort in the power sector so as to achieve availability of electricity power without interruptions. These will reduce frustrations often experienced due to equipment idleness and frequent break down occurrences in institutions of learning.

\section{Conclusion}

No nation can develop in the modern world without a viable, well structured, culturally adapted and functional education system. The indices of qualitative education system are many and Nigeria has been known to be amazingly deficient in educational delivery at all levels. The challenges presented for discussion in this paper are the products of education reports from stakeholders in the Nigerian education system, including parents and other members of the public, research reports and frequent calls for reforms, teachers and students and, of course, Nigerians in Diaspora who are witnessing the influx of Nigerian youths into other countries like Ghana, South Africa and Botswana that have better education systems. This has been a worrisome development. According to a revelation by theGovernor of the Central Bank of Nigeria, SanusiLamido, Nigeria ranks third among countries with the highest number of students studying overseas.

Sanusi also said, through the revelation by the Network of Migration Research on Africa (NOMRA), a migration research group, that about 10,090 Nigerians were granted visas into the United Kingdom in 2011 and they paid $\$ 42$ Billion to their host nation(NOMRA,2012). From this, one can deduce that Nigerians migrate abroad in search of good education in systems that are well positioned to train their youth and prepare them for effective participation in and contribution to the development of their nations. Nigerian education has not measured to expectation because our leaders, from the period of military rule till date, have seen no reason why they should invest in and focus on this sector that is so vital to national development. 
We have attempted to diagnose the ailment of the Nigerian Education system. In particular, we have highlighted the numerous challenges that bedevil the system to the extent of very low ranking in global assessment. The malaise is not insurmountable and a number of useful suggestions which, if carefully considered and implemented can potentially revive the system, have been made. The system should be able to produce the quality of manpower needed to put Nigeria's natural resources into use for faster economic growth, national advancement, and for the country to become a global focal point in the years ahead. 


\section{REFERENCES}

Adaralegbe, A. (ed.)(1972). A philosophy for Nigerian Education,Report of the National Curriculum Conference, Sept 8 - 12, 1969. Ibadan,Heinemann Educational Books Nig. Ltd.

Adiele,E.E.(2007).The Imperative for Educational Reforms in Nigeria.Nigerian Journal ofEducational Philosophy, 3: 21.

Akinkpelu,J.A.(2005).Themes in Philosophy of Education for Teachers.Ibadan.Tafak Publications.

Asabor,B.M.(2009). 'School Plant Development and Maintenance in Primary and SecondarySchools' Universal Basic Education inNigeria,Arubaye\&Whawo(eds.),p.310 -319 .

ASP-NNPC:Annual Statistics Bulletin (2004).

www.nnpcgroup.com/publicrelations/annualstatisticsbulletin.aspx. Accessed 10/2/2013.

Bukar,I.B.; Mwajim,A.U. \&Kadiri,D. (2012). The Implementation of Universal Basic Education: The Journey so far Borno, Bauchi and Taraba States, Nigeria. SokotoEducational Review,13(2): 235.

Dewey, J.

(2007).DemocracyandEducation.http:www.worldwideschool.org/library/books/socl/ed ucation/Demo., p.11,Accessed on May 7, 2013.

Federal Government of Nigeria (2004). National Policy on Education, Lagos, NERDC Press, p 6.

Ebuta,E.E.(2012). Reconstructionism in Education and Development: A philosophical Perspective. Nigeria Journal of Educational Philosophy, 23 (1): 18.

Iyamah,C.C.(2009). 'Qualitative Education Delivery and Private Sector Partnership in Nigeria'Universal Basic Education in Nigeria,Arubaye\&Whawo(eds.),p.117 - 181 .

Jain, A.K. (2001). Corruption: A Review. Journal of Economic Surveys, 15(1): 71 - 121.

JAMB, (2013). Admissions \& Statistics.www.jamb.gov.ng/jamb/applicationstat.aspx.

Mahmoud, S.S.\&Madori, H. ( 2013). 'Education: Problems and challenges in Nigeria, what to be done?'www.sundaytrust.com.ng/index.php/comment-debate/12514education. Retrieved 22/11/2013.

Nigeria Investment Promotion Commission(NIPC):Solid Mineral Deposits inNigeria,www.npic.gov.ng/deposit.html,Retrieved 13/09/2013

Sanusi,L(2012). Network of Migration Research inAfrica(NOMRA):nomra.files.wordpress.com/2012/06/nomranewsletterapril.pdfAccessed23/11/2013. 
Okandeji, (2007). 'Total Quality Management of Education in Nigeria: an imperative for achieving Sustainable development' Journal of School of Arts and Social Sciences, COEWA.p.59-71.

Omoraka, V.O. (2009). "Meal ticket syndrome and the pursuit of certification" Educology, 3(1):.96.

Well-Strand,A. (2000). Knowledge production, service and quality: higher education tensions in Norway. Quality in Higher Education, 6(3): 219-230. 